\title{
Elastolytic activity of alveolar macrophages in chronic bronchitis: comparison of current and former smokers
}

\author{
S O'NEILL, JS PRICHARD \\ Department of Clinical Medicine, Trinity College, Dublin, St James's Hospital, Dublin
}

\begin{abstract}
We have compared the macrophage elastolytic activity of a group of current and former smokers with irreversible airflow obstruction. Elastolytic activity was determined in an initial bronchoalveolar lavage cell population and in alveolar macrophages cultured for three days, to investigate whether enhanced macrophage elastolytic activity alone is a determining factor in the susceptibility of some smokers to obstructive lung disease. Twenty current smokers and 12 former smokers who had abstained from smoking for at least three years were studied. All patients had spirometric evidence of irreversible air flow obstruction. Current smokers had a cell yield (mean \pm SD) of $138.7 \pm 36.4 \times 10^{6}$ cells (alveolar macrophages $94.2 \% \pm 2.1 \%$ ) compared with $31.4 \pm 14.1 \times 10^{6}$ cells (macrophages $86.5 \% \pm 4.7 \%$ ) in former smokers. Elastolytic activity in the initial lavage cell population from current and former smokers, measured with the synthetic elastase substrate succinyl-L-alanyl-L alanyl-L-alanine- $p$-nitroanilide, and expressed as the equivalent of $1 \mu \mathrm{g}$ of porcine pancreatic elastase, was respectively $0.113 \pm 0.003$ and $0.096 \pm$ $0.004 \mu \mathrm{g}$ pancreatic elastase $/ \mathrm{mg}$ cell protein. After three days in culture macrophage elastolytic activity in the current and former smokers' cells was respectively $0.107 \pm 0.006$ and $0.011 \pm$ $0.001 \mu \mathrm{g}$ pancreatic elastase/mg cell protein $(\mathrm{p}<0.05)$. The elastase activity of the cultured alveolar macrophages from five current smokers had the inhibitor profile of a metalloproteinase. Our results indicate that enhanced macrophage elastolytic activity alone is not a determining factor in the susceptibility of some smokers to develop obstructive lung disease.
\end{abstract}

The proteolytic theory of the pathogenesis of emphysema suggests that the balance between elastase activity and its inhibition is altered, in certain susceptible patients, by exogenous factors such as smoking or endogenous factors such as $\alpha_{1}$ antiproteinase deficiency, with resultant elastinolysis. Alveolar macrophages may be important in the pathogenesis of centrilobular emphysema of cigarette smokers for the following reasons. An expanded alveolar macrophage population is found in the region of the terminal bronchioles in young smokers. ${ }^{1}$ In normal subjects bronchoalveolar lavage yields four to five times more cells in smokers than in non-smokers, $95 \%$ of these cells being alveolar macrophages. ${ }^{23}$ Alveolar macrophages from smokers show greater elastolytic activity during in vitro culture and release more elastolytic activity

Address for reprint requests: Dr S O'Neill, Section of Respiratory Diseases, Department of Medicine, University of Manitoba, 700 William Avenue, Winnipeg, Manitoba, R3E 0Z3, Canada.

Accepted 7 January 1983 into conditioned media in vitro ${ }^{4}$ than do macrophages from non-smoking normal subjects.

All previous studies, however, have compared elastolytic activity of alveolar macrophages from normal smokers and non-smokers. As only a proportion of smokers will develop significant lung disease, we thought that studies of a group of current and former smokers with obstructive lung disease were necessary to explore the question of whether enhanced macrophage elastolytic activity alone is a determining factor in the susceptibility of some smokers to lung disease.

\section{Methods}

We studied 20 current smokers and 12 former smokers who had abstained from smoking for at least three years (mean $5 \cdot 1$, range $3-10 \cdot 2$ years). Both the current and the former smokers had consumed at least 20 cigarettes a day for at least 10 years. All had grade 3 or 4 dyspnoea $^{6}$ and currently fulfilled criteria for chronic bronchitis. ${ }^{7}$ Spirometry 
(performed with a Vitalograph spirometer in the sitting position) indicated irreversible airflow obstruction $\left(\mathrm{FEV}_{1}\right.$ and $\mathrm{FEV}, / \mathrm{FVC}$ ratio less than $60 \%$ of predicted, with less than $10 \%$ increase in FEV 15 minutes after inhalation of $200 \mu \mathrm{g}$ salbutamol on three separate occasions) in all patients.

The mean FEV was $42.7 \%$ (SD $\pm 6.2 \%$ ) of the predicted value. The mean age of the patients was 59.9 years and the range $42-68$ years. All patients gave informed consent to the study, which had been approved by the hospital ethics committee. They were all being investigated because of a solitary pulmonary nodule and none had noted recent change in sputum characteristics or degree of dyspnoea and none had fever or leucocytosis. Lavage was performed on the lung opposite to the nodule.

Bronchoalveolar lavage was performed with $50-\mathrm{ml}$ aliquots of sterile, warm $\left(37^{\circ} \mathrm{C}\right)$ phosphatebuffered normal saline to a total of $300 \mathrm{ml}$, through the tip of a fibreoptic bronchoscope wedged in a subsegmental bronchus of a lower lobe. The fluid recovered (about half of the instilled volume) was placed in sterile, plastic, conical centrifuge tubes, chilled to $4^{\circ} \mathrm{C}$, and centrifuged at $1000 \mathrm{~g}$ for 10 minutes, within 30 minutes of aspiration. The cells were washed three times with Hank's Balanced Salt Solution. A portion of cells was suspended in the Hank's Solution at a concentration of about $1.0 \times 10^{7}$ cells $/ \mathrm{ml}$ and was used directly for enzyme assays and differential cell counts (made from both Wright's and non-specific-esterase-stained preparations with $\alpha$ naphthyl butyrate).$^{8}$

The remaining cells were cultured in NeumanTytell serum-free medium (Gibco-Biocult), 1-ml suspensions in $35 \mathrm{~mm}$ petri dishes (Falcon) being used. After three hours the cultures were washed to remove non-adherent cells, and fresh medium was added. The medium was also changed at 24 and 48 hours. Cell viability was assessed by measuring release of lactate dehydrogenase into the medium. ${ }^{9}$

Tissue culture medium was prepared for assay by centrifugation at $500 \mathrm{~g}$ for 10 minutes and dialysis of 4-ml aliquots against $10 \mathrm{mmol} / \mathrm{l}$ tris- $\mathrm{HC} 1$ (pH 7.6) containing $1 \mathrm{mmol} / \mathrm{l} \mathrm{CaC1}$, for 48 hours, after which the material was lyophilised. Before assay the lyophilisate was reconstituted with cold distilled water to $5 \%$ of the original volume.

Cultured cells were prepared for assay by scraping adherent macrophages from dishes into Hank's Solution, and membranes were disrupted by sonification for 1 minute at $0^{\circ} \mathrm{C}$. Myeloperoxidase activity $^{10}$ was used as an index of contamination by polymorphonuclear leucocytes, because the enzyme is not found in human lymphocytes ${ }^{11}$ and cannot be detected in cultured alveolar macrophages.

Elastolytic activity was measured by hydrolysis of succinyl-L-alanyl-L-alanyl-L-alanine-p-nitroanilide (SLAPN, Bachem Feinchemikalien AG, Bubendorf, Switzerland), a synthetic substrate which detects amidolytic activity and is probably specific for neutrophil, pancreatic, and macrophage elastase. ${ }^{12}$

Hydrolysis of $1.35 \mathrm{mg}$ of SLAPN with $20 \mu \mathrm{l}$ of cell lysates or tissue culture medium was carried out at $37^{\circ} \mathrm{C}$ in $3 \mathrm{ml}$ of $0.2 \mathrm{~mol} / 1$ tris $\mathrm{Hcl}$ with $50 \mathrm{mmol} / 1$ $\mathrm{CaCl}_{2}$, and change in absorbance was measured at $410 \mathrm{~nm}$. Standards of porcine pancreatic elastase (Sigma Chemical Co) were run simultaneously for comparison. All activity is expressed as the equivalent of $\mu \mathrm{g}$ pancreatic elastase per $\mathrm{mg}$ of cell protein. Protein was assayed by a Lowry procedure. ${ }^{13}$ Elastase inhibition studies were performed on five of the current smokers with the serine proteinase inhibitors soya-bean trypsin inhibitor and phenylmethanesulphonyl fluoride and the metalloproteinase inhibitor EDTA (all inhibitors purchased from Sigma Chemical Co). Samples were preincubated for 30 minutes at $37^{\circ} \mathrm{C}(\mathrm{pH} \mathrm{7.8)}$ with the inhibitor before SLAPN was added, and the assay was then performed as previously described. The terms elastase and elastolytic activity, where they are used in the context of our present findings, indicate activity measured by this assay.

Statistical data are presented as the means \pm 1 standard deviation. Student's $t$ test for paired or unpaired variables was used to determine the significance of any difference.

\section{Results}

Current smokers had a mean cell yield of $138.7 \pm$ $36.4 \times 10^{6}$, in contrast to $31.4 \pm 14.1 \times 10^{6}$ in former smokers $(p<0.01)$. The mean percentage of alveolar macrophages was $94.2 \pm 2 \cdot 1$ in the current smokers and $86.5 \pm 4.7$ in the former smokers. Lymphocytes comprised $3.0 \% \pm 3.6 \%$ and $10.3 \%$ $\pm 4.9 \%$ respectively and polymorphonuclear leucocytes $2.8 \% \pm 2.7 \%$ and $3.2 \% \pm 3.8 \%$.

Data on elastolytic activity with SLAPN are presented in the figure. The initial elastase activity in cells from 20 current smokers and 12 former smokers, all of whom had detectable activity, was equivalent to $0.113 \pm 0.003$ and $0.096 \pm 0.004 \mu \mathrm{g}$ pancreatic elastase/mg of cell protein respectively; these values are not significantly different. Unfortunately, sufficient cells were available from only 10 of the former smokers for culture studies. After culture of the lavaged cells from both the groups studied for three days no polymorphonuclear leucocytes were detected by light microscopy (Wright's stain of cover slip preparation), no myeloperoxidase activity was detected in either the cells or the final culture 


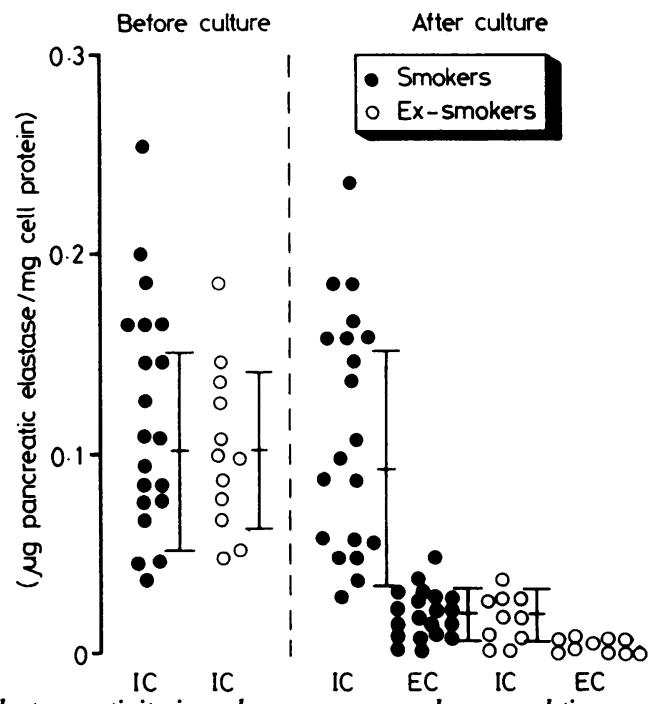

Elastase activity in pulmonary macrophages and tissue culture medium from smokers and ex-smokers (activity expressed as equivalent of pancreatic elastase). IC-cellular activity; EC-activity in extracellular (tissue culture) medium.

Effect of serine and metalloproteinase inhibitors on SLAPN elastase activity

\begin{tabular}{|c|c|c|c|}
\hline \multirow[t]{2}{*}{ Inhibitor } & \multirow[t]{2}{*}{ Concentration } & \multicolumn{2}{|l|}{$\%$ inhibition } \\
\hline & & $\begin{array}{l}\text { Human alveolar } \\
\text { macrophages in } \\
\text { culture elastase }\end{array}$ & $\begin{array}{l}\text { Porcine } \\
\text { pancreatic } \\
\text { elastase }\end{array}$ \\
\hline $\begin{array}{l}\text { Phenylmethane- } \\
\text { sulphonyl }\end{array}$ & $0 \cdot 1$ & 0 & 5 \\
\hline $\begin{array}{l}\text { fluoride } \\
(\mathrm{mmol} / \mathrm{l})\end{array}$ & $1 \cdot 0$ & 0 & 99 \\
\hline $\begin{array}{l}\text { Soya-bean } \\
\text { trypsin } \\
\text { inhibitor } \\
(\mathrm{mg} / \mathrm{ml})\end{array}$ & $\begin{array}{l}0 \cdot 2 \\
1 \cdot 0 \\
5 \cdot 0\end{array}$ & $\begin{array}{l}0 \\
0 \\
0\end{array}$ & $\begin{array}{l}10 \\
25 \\
95\end{array}$ \\
\hline $\begin{array}{l}\text { EDTA } \\
(\mathrm{mmol} / \mathrm{l})\end{array}$ & $\begin{array}{l}1 \cdot 0 \\
5 \cdot 0 \\
50\end{array}$ & $\begin{array}{l}64 \\
88 \\
97\end{array}$ & $\begin{array}{l}0 \\
0 \\
0\end{array}$ \\
\hline
\end{tabular}

SLAPN—succinyl-L-alanyl-L-alanyl-L-alanine-p-nitroanilide.

medium, and at 48 hours $30 \%$ of the total lactate dehydrogenase activity was extracellular. The elastase activity in the cultured macrophages from current smokers and former smokers was equivalent to $0.107 \pm 0.006$ and $0.011 \pm 0.001 \mu \mathrm{g}$ pancreatic elastase/mg cell protein respectively $(p<0.05)$. The difference reflects the negligible elastolytic activity of cultured alveolar macrophages from former smokers, four of whom had no detectable activity. The levels of elastolytic activity were similar to those found previously in smoking and non-smoking nor- mal subjects ${ }^{45}$ and may reflect an enhanced biosynthetic activity of smokers' alveolar macrophages. ${ }^{4}$

The extracellular elastase activity in the final tissue culture medium was measured. No activity was detected in the former smokers. The current smokers had a mean activity of $0.012 \pm 0.001 \mu \mathrm{g}$ pancreatic elastase/mg of cell protein.

The inhibition profile of the SLAPN elastase activity of the cultured alveolar macrophages from five current smokers is given in the table. The elastase activity has the features of a metalloproteinase, as indicated by inhibition by EDTA and by the lack of inhibition with phenylmethanesulphonyl fluoride and soya-bean trypsin inhibitor. ${ }^{45}$

\section{Discussion}

These observations suggest that cessation of smoking for at least three years in patients with chronic bronchitis is associated with reduction in total lavage cell counts and in elastolytic activity of an in vitro culture of alveolar macrophages.

The total and differential cell counts obtained by lung lavage in our groups of current and former smokers follow a pattern similar to that previously observed in normal smoking and non-smoking subjects. ${ }^{23}$ There was no significant difference between current and former smokers in elastolytic activity per mg cell protein of the initial lavage cell population, although the greater number of cells (four to five times more) in the the current smokers imposes a potentially greater elastase burden on the lungs of these subjects. The alveolar macrophages from current smokers, after in vitro culture for three days, showed a degree of elastolytic activity similar to that found in the initial lavage cell population and released SLAPN elastase activity into the culture medium that had the characteristics of a metalloproteinase rather than a serine proteinase. ${ }^{414}$ In contrast, the cultured alveolar macrophages from former smokers showed a negligible degree of elastolytic activity, about $10 \%$ of the activity of the initial lavage cell population, and released no SLAPN elastase activity into the culture medium. The inhibition profile of the SLAPN elastase activity of cultured alveolar macrophages from former smokers was not determined. Previous studies in smoking and non-smoking normal subjects ${ }^{4}$ have shown similar degrees of elastolytic activity, with a decline in the SLAPN elastase activity of non-smokers' macrophages to negligible levels after in vitro culture for three days. The failure of smokers' macrophages to show this decline may be due to an enhanced biosynthetic activity in their macrophages. It could also be argued that the decline in elastolytic 
activity represents metabolism of internal neutrophil elastase, although without inhibition studies of the SLAPN elastase activity of the macrophages of former smokers before culture this remains uncertain.

Our results are similar to those in normal subjects studied previously and suggest that enhanced macrophage elastolytic activity on its own does not explain why only some smokers develop obstructive lung disease. This study examines only one facet of a potential proteinase-antiproteinase imbalance. An expanded alveolar macrophage population with enhanced elastolytic activity may yet be shown to be important in the pathogenesis of emphysema, acting in concert with neutrophil elastase to induce elastinolysis in susceptible patients with smokinginduced functional $\alpha_{1}$-proteinase inhibitor deficiency. Support for this idea comes from the following observations: normal smokers have increased numbers of neutrophils in their bronchoalveolar fluid, ${ }^{2}$ thought to be secondary to release of neutrophil chemotactic factors by smoke-stimulated alveolar macrophages ${ }^{15}$; cigarette smoke condensate can induce elastase release from neutrophils both by producing cytotoxic reactions and by stimulating secretion from viable cells ${ }^{16}$; functional $\alpha_{1-}$ proteinase inhibitor deficiency has been found in the bronchoalveolar fluid of normal smokers (about $60 \%$ of the activity of non-smoking controls). ${ }^{17}$ Further studies which include patients with established obstructive lung disease, in addition to normal smokers and non-smokers, are necessary for exploring the proteolytic theory of the pathogenesis of emphysema in susceptible smoking subjects.

The authors wish to thank the Wellcome Foundation, which through a grant to Trinity College, Dublin, provided support for JSP's salary and for the purchase of equipment and reagents.

\section{References}

' Niewoehner DE, Kleinerman J, Rice DB. Pathologic changes in the peripheral airways of young cigarette smokers. N Engl J Med 1974;291:755-8.
${ }^{2}$ Reynolds HY, Newball HH. Analysis of proteins and respiratory cells obtained from human lungs by bronchial lavage. J Lab Clin Med 1974;84:559-73.

${ }^{3}$ Harris JO, Swenson EW, Johnson JE. Human alveolar macrophages:comparison of phagocytic ability, glucose utilization, and ultrastructure in smokers and non-smokers. J Clin Invest 1970;49:2086-96.

${ }^{4}$ Hinman LM, Stevens CA, Matthay RA, Gee JBL. Elastase and lysozyme activities in human alveolar macrophages: effects of cigarette smoking. Am Rev Respir Dis 1980;121:263-71.

s Rodriguez RJ, White RR, Senior RM, Levine EA. Elastase release from human alveolar macrophages: comparison between smokers and non-smokers. Science 1977;198:313-4.

- Medical Research Council. Questionnaire on respiratory symptoms. 2nd ed. London: Medical Research Council, 1977.

${ }^{7}$ Fletcher CM, ed. Terminology, definitions and classification of chronic pulmonary emphysema and related conditions. Thorax 1959;14:286-99.

${ }^{8} \mathrm{Li} \mathrm{CY}$, Lam KW, Yam LT. Esterases in the human leukocyte. J Histochem Cytochem 1973;21:1-12.

${ }^{9}$ Stolzenbach F. Lactic dehydrogenases (crystalline). In: Colowick S, ed. Methods in enzymology. Vol 9. New York: Academic Press, 1966:278-88.

${ }^{10}$ Chance B, Maehly AC. Assay of catalases and peroxidases. In: Colowick S, ed. Methods in enzymology. Vol 2. New York: Academic Press, 1955:764-75.

11 Adler LM, Gee JBL, Root RK. $\mathrm{H}_{2} \mathrm{O}_{2}$ formation and utilisation by human monocytes. Clin Res 1978;26:522 (abstract).

12 Bieth J, Wermuth CG. The action of elastase on p-nitroanilide substrates. Biochem Biophys Res Commun 1973;53:383-390.

${ }^{13}$ Lowry OH, Rosebrough NJ, Farr AL, Randall RJ. Protein measurement with the folin phenol reagents. $J$ Biol Chem 1951;193:263-75.

14 Banda MJ, Werb Z. Mouse macrophage elastase. Purification and characterization as a metalloproteinase. Biochem J 1981;193:589-605.

15 Hunninghake GW, Gallin JI, Fauci AS. Immunological reactivity in the lung: the in vivo and in vitro generation of a neutrophil chemotactic factor by alveolar macrophages. Am Rev Respir Dis 1978;117:15-23.

${ }^{16}$ Blue ML, Janoff A. Possible mechanisms of emphysema in cigarette smokers. Release of elastase from human polymorphonuclear leukocytes by cigarette smoke condensate in vitro. Am Rev Respir Dis 1978;117:317-25.

${ }^{17}$ Gadek JE, Fells GA, Crystal RG. Cigarette smoking induces functional antiprotease deficiency in the lower respiratory tract of humans. Science 1979;206:13156. 